\title{
Dismantling of the Dominant European Discourse in the Poetry of Jeanine Leane
}

\author{
Danica Čerče \\ danica.cerce@ff.uni-lj.si \\ Faculty of Arts, \\ University of Ljubljana, Slovenia
}

\begin{abstract}
Until very recently a marginalised voice in Australian literary studies, Australian Indigenous literature has obtained an important role in the articulation of Indigenous peoples' political thought, constituting an indictment of white Australian racism, a recuperation of neglected Aboriginal history, and a call for change. Based on the premise that literature can play an important role in both maintaining and disrupting the exercise of power, and written against the backdrop of post-colonial theory, the article deals with the collection of poems Dark Secrets: After Dreaming A.D. 1987-1961 (2010) by the contemporary Australian Indigenous author Jeanine Leane. Taking Leane's poetry as exemplary of post-colonial textual resistance to colonialist representations, the article shows how the poet, relying on the "transgenerational blood memory" intervenes in the presupposed irreducible division between subjugating and subjugated cultures, that is, the assumptions about whiteness as a static privilege-granting category and a system of dominance upon which the logic of coloniality often stands. I argue that, by mobilising various techniques and strategies to challenge the reproduction of whiteness and affirm Indigenous Australians' authentic, rather than an imposed cultural personality, Leane's verse performs both personal and collective empowerment of Indigenous Australians, and represents an important site for the renegotiation of inter-racial relationships.
\end{abstract}

Keywords: Australian Indigenous poetry; destabilising whiteness; Indigenous identity; representation and protest; socio-economic and political critique

\section{INTRODUCTION}

Critics tend to concur with Brisbane's assertion that one of the most consistent preoccupations of contemporary Australian literature has been "the past bearing down upon the present" (1996, p. xv). Of the two main traumas that are in the centre of Australian consciousness - Australia as a British penal colony, as it was its first function, and the devastating impact of invasion and settlement of whites on the country's Indigenous population ${ }^{1}$ - only the former has been explored extensively, while the latter has not received much penetrating and thoughtful treatment in the mainstream Australian literature. This is hardly surprising given that the history of white Australian domination of Indigenous Australians, marked by sustained brutality, oppression and genocidal horror, does not conform to the country's highly esteemed view of itself.

At the turn of the new millennium, the progressive part of Australian politics interrupted a long-standing tradition of denial and silence by publishing reports with alarming data about the Indigenous Australians' struggle for their cultural and biological survival. However, it was not until February 2008 that the Prime Minister, Kevin Rudd, opened a new chapter in Australia's relations with its Indigenous peoples by making a comprehensive apology for the past policies (Johnston, 2008, p. 3). By affirming their longest continuous presence in Australia, the Prime Minister challenged the country's false philosophy of its historical continuity $^{2}$ and started the process of reconciliation. This development was meant to put an end 
to the injustice and indifference that had thus far prevailed; however, social inequities are still in place, adding fuel to the Indigenous population's collective effort to assert their rights and deconstruct the historical memory that white Australia had imprinted for years in literary works and in the people's consciousness. With its "ideological construct," as Amin (2009) defines the discourse that assumes or explicitly declares the superiority of all those who were born speaking modern European languages, white Australia is still largely incapable of surpassing the stereotypical images of Indigenous people as second-class citizens (p. 5).

Those who refuse to regard cultural hierarchy as an indisputable fact and oppose to the concomitant division in 'superior' and 'inferior' cultures, find the construction of Indigenous identity as an inferior social group vital in establishing and maintaining what Mills (2000) refers to as the "social contract" in which inequality and domination are the norm (p. 445). Of course, the Indigenous identity formed on the basis of false paradigm of duality is not the reflection of reality but merely a construct of white consciousness. The rejection of the colonialist myth about the "fixity of the dividing lines" between imperial power and disempowered culture is also the main driving force behind the literary production of Jeanine Leane, a member of the Wiradjuri tribe in New South Wales (Suleri, 2003, p. 112). ${ }^{3}$ Drawing on some of the issues and debates in the field of critical whiteness studies and in light of the view that literature can play an important role both in "forming and reforming the identities of individuals, social groups and communities," as Juvan has observed (2006, p. 29), I therefore aim to show how the poet's socio-critical rhetoric in her collection Dark Secrets: After Dreaming A.D. 1987-1961, here after referred to as Dark Secrets, challenges the misconception about the superiority of the white race in relation to all 'others.' I argue that, by reappraising the Australian history through "informed imagination," that is, filling the gaps missing or intentionally left out of the official records with voices from the past that recall and remember the traumas and resilience of Indigenous population through "blood memory" (Leane, 2017, 242), Leane's poetry intervenes in the "exclusionary" concept of whiteness (Lipsitz, 2006, p. 4), held in place to preserve the racialised notions of Australian identity. By doing this, it participates in the recuperation of Indigenous Australians' independent or pre-colonised local identity and returns them dignity and social hope. ${ }^{4}$

Dark Secrets (2010) is not only Leane's first volume of poetry but also her first literary work. My reading of this collection, which, in the year of publication, won the Scanlon Prize for Indigenous Poetry, ${ }^{5}$ is not concerned with the 'literariness' as a principal object of study and appreciation. Rather, it is framed by an interest in how this volume functions as "a form of public good" (Gonzales \& Agostini, 2015, p. xvi) or how it contributes to the "independence, growth and vitality of Indigenous cultures," and thus performs the role highlighted by Melissa Lucashenko in her keynote address given on the occasion of the 2012 Black Words Symposium ${ }^{6}$ (Kilner \& Minter, 2014).

\section{THE CONTOURS OF THE CURRENT SOCIAL SITUATION IN AUSTRALIA}

Leane's creative urgency to respond to colonial legacies coincides with the collective need of Indigenous Australians to intervene in the processes and logics that have largely retained the Australian Indigenous population in the position of "hegemonic dependency" (Mignolo, 2005, p. 381). Several critics have noted that, despite the progressive suppression of Australian discriminatory legislation following the success of 1967 referendum, ${ }^{7}$ held to alter the Australian constitution and recognise the Indigenous peoples as full Australian citizens, the latter have not been granted "the deserved discursive and material space" in Australian society and identity formation (Renes, 2016, p. 93). Drawing on Ranajit Guha, Brewster (2008) claims that Australia has maintained a "dominance without hegemony" (p. 59) in relation to its Indigenous population, that is, a "constituency that [...] has never ceded sovereignty" (p. 60). 
Similarly, Griffiths questions whether Australia has moved beyond colonialism, given that Indigenous peoples in Australia "continue to be colonised" (2013, p. 15).

That the majority of Indigenous Australians, decimated in the process of genocide, expropriation, forced labour and the removal of children from their parents, ${ }^{8}$ still live in conditions of politically sustained subalternity, which, in Mignolo's words, "foregrounds racialised oppression and socio-economic subordination" $(2005$, p. 381$)$, is reflected in high unemployment rate, poor health-care, poverty, and an acute lack of education among them. ${ }^{9}$ Poverty, coupled with poor housing and malnutrition, has resulted in high rates of disease, particularly diabetes and chronic cardiovascular diseases. According to the Australian Institute of Health and Welfare's 2018 report, there are also significant disparities in child mortality and life expectancy between Indigenous and non-Indigenous Australians. Similar statistics apply to drug and alcohol abuse, as well as to family violence. ${ }^{10}$ The real dimensions of these disparities did not become collective awareness before the publication of several anthropological studies in the first decade of the $21^{\text {st }}$ century, particularly those by Sutton (2001) and Nowra (2007). Writing about the US context, Mills (2000) exposes the "systemic privileging of whites," apparent in the country's social, economic, and political structures (p. 449). The same could be said of Australian society. As I have argued elsewhere, ${ }^{11}$ positioned as a subjugated culture, Indigenous communities continue to manifest their protests against the racialised nature of social policy in Australia, demanding full citizenship, rather than being "the people / of no life / and no hope," as a Western Australian Nyoongah poet Alf Taylor writes (Moreton, Taylor \& Smith, 2000, p. 125).

In addition to various forms of activism, literature has obtained a vital role in giving impetus to the Indigenous peoples' struggle for reform. Reappraising Australian social history from Aboriginal perspectives, Indigenous authors have become involved in the production that used to be reserved as the "exclusive domain of Europeans" (Brewster, 2015, p. xii). By articulating criticism of and resistance to colonial rule, they participate in redefining the hegemony of the English language and the white nation and develop spaces of reciprocal understanding and communication between the mainstream and the Indigenous populations, or in Suleri's words, "the peculiar intimacy" that produces an idea of "nation that belongs neither to the coloniser nor to the colonised" (2003, p. 113).

\section{AUSTRALIAN INDIGENOUS LITERATURE AS A SITE OF RESISTANCE}

In theorising the issue of colonialist relations, Ashcroft, Griffiths and Tiffin (2003) have observed that much of the drama of these relations and the postcolonial examination and subversion of them has taken place within vast areas of "representation and resistance" (p. 85). Until very recently, textual representations of Australian past have been provided by Australian mainstream authors and have been characterised by a highly pronounced view about the deficiency of Indigenous population. It was not before the end of the 1970s that the authority of those with the monopoly on representation started to be destabilised with a sudden growth in Indigenous Australian authorship. For Indigenous authors, writing seems to have forged new possibilities for asserting their identity and conveying their demand for the displacement of all sites of discrimination and domination. In a political system in which Indigenous population is almost non-existent and in which the official history does not record all the facts, literature has become the medium that gives them a voice, contend Heiss and Minter (2008) in their introduction to Anthology of Australian Aboriginal Literature (p. 2).

There is no shortage of evidence that writing has played a major role in both establishing whites as authoritative in relation to non-white subjects and in the processes of decolonisation. The latter have involved "a radical dismantling of European codes and a postcolonial subversion and appropriation of the dominant European discourses," claims Tiffin 
(2003, p. 95). Interrogating these discourses and the existing social context in which white bodies "dominate in the name of a cultural supremacy" (Bhabha, 1994, p. 51), literary engagement of Indigenous Australians can be seen as "an integral part of an organised struggle" against colonialist authority (Slemon, 2003, pp. 107-108).

Davis \& Chesson (1988) consider writing as "the best means of influencing public opinion and bringing about an improvement in the Aboriginal situation" (p. 191), whereas several others emphasize its healing role. For the last four decades, Australian Indigenous literature has successfully performed both educative and healing function by constituting an indictment of white Australian racism, a re-mapping of Australian archives, and a call for change. Articulating discourses of "conscious antagonists," as Said (1994) refers to those who, "compelled by the system to play subordinate or imprisoning roles within it," react by "disrupting it" (p. 335), Australian Indigenous literature surely deserves the label "literature with a purpose" (Weaver, 1997, p. 44), applied to postcolonial literatures of Latin America, Caribbean Islands, Sub-Saharan Africa, South Asia and several others that "write back"12 to the literary traditions of empire and their white literary subjectivity (Čerče, 2017).

Sharing with these literatures the fact of having "asserted [itself] by foregrounding the tension with the imperial power, and by emphasizing the differences from the assumptions of the imperial Centre" (Ashcroft, Griffits \& Tiffin, 1989, p. 2), Australian Indigenous literature deconstructs the colonialist cultural relations. Bhabha (1997) has asserted that, with the notion of irreversible binarisms, such as domination and subordination, centre and margin, self and other, as an important feature of these relations, and the production of discriminatory stereotypical identities as a vital concept that enables and justifies them, it is necessary to "recognise the stereotype as an ambivalent mode of knowledge and power," and "demand a theoretical and political response that $[. .$.$] questions dogmatic and moralistic positions on the$ meaning of oppression and discrimination" (p. 293). Intervening in Australia's "colonialcontinuum of history" (Harkin, 2014, p. 10) and affirming their peoples' syncretic, dynamic, and adaptive identities, Indigenous Australian authors do just that and continue to "disturb" what Crow and Banfield (1996) call "the nostalgic, myth-laden account so beloved of many white Australians" (p. 77).

Poetry seems to have attracted more Indigenous Australians than any other mode of creative expression and the distinctive feature of much of contemporary Indigenous verse is its political and social critique. In one of her poems, Moreton (2004) writes: "It ain't easy being black / this kinda livin' is all political" (p. 111). Indeed, the distinctive feature of much of contemporary Indigenous verse produced by Moreton, Taylor, Smith, Bellear, Claire, Burke, Leane and several others, is its political or social critique in objecting to what Mills (2015) calls the "majoritarian white perspective" - a centuries-long legacy of "holding and benefiting from the supposedly superior race" (p. 45). Another essential aspect of protest poetry is its capacity to stimulate readers' empathy with those who suffer from a particular social ill (Netzley, 1999, p. xiii). As this discussion will also show, Australian Indigenous poetry, and Leane's verse, in particular, is capable of ensuring strong effect on its readers.

This is so because Leane is a poet with the pronounced sensitivity to typical Aboriginal themes and ability to connect intense personal feeling with penetrating critical thought. In her poetry, grief and pain intertwine with anger and disappointment. In exposing social anomalies resulting from the logic that has enabled the ongoing dominant position of whites on the one hand, and the concomitant political, economic, and cultural subordination of Indigenous population on the other, Leane is driven by deep personal engagement and generative urgency. In addition to strong arguments, it is precisely this ability to bring her whole sensibility to bear upon her writing that ensures a strong affective impact of her verse. To elicit readers' empathy, Leane employs various linguistic structures, such as rhetorical questions, satirical antitheses, repetitions, and direct addresses to the reader, which all invite active participation through 
emotional identification and personal or collective response. With the focus on the participatory aesthetic of Leane's work, a firm synthesis of author, text and reader, and following the poet's spirited deconstruction and reconstruction of colonial archiving, the next chapter will be dealing with the poems that I find among the most illustrative of post-colonial textual resistance to colonialist representations.

\section{DARK SECRETS AS COUNTER-DISCOURSE ${ }^{13}$}

A short text on the back of Dark Secrets reads that the collection, "inspired by anecdotal and family stories of Wiradjuri women, moves from campfire to captivity and confinement and through colonisation." In this process, producing a counter-reading of the archival and cultural memory through "transgenerational blood memory" (Leane, 2017, p. 250), Leane makes important statements on various forms of racism inscribed within the Australian society. Of thirty-two poems that comprise the collection, some are merely short momentary remarks, flashes of wit torn from the context, but always arising from deeply felt emotional pain. As such, they hit hard. In line with Fynsk's observation that "literature addresses an anonymous collective but convokes us as singular beings" (1991, p. xxviii), they evoke emotional and cognitive states in the readers, and solicit affective responses. Leane's poetry addresses both non-Indigenous and Indigenous readers. The former are urged to re-assess the Australian social history and the "way that they as a group have been taught to think about Indigenous Australians," as Leane (2010) writes in her study with the indicative title "Aboriginal Representation: Conflict or Dialogue" (p. 38). The latter are reminded of their ancestors and rich cultural heritage, of the time, when "the whole country was one big kitchen" and "the pantry was never empty" (Leane, 2010, 14). The poet seems to be aware of the power of representation and dangers that stereotypes pose, or - as Sartre (1965) noted- of "allow[ing] to be poisoned by the stereotypes that others have of [us]" (p. 95).

In light of the view that writing can either "enslave or emancipate," Johnson (1990) argues that "what enslaves is not writing per se but control of writing and writing as control" (p. 48). Rather than accounts of different peoples and societies, European texts were an important part of imperial practice, constituting and disseminating the derogatory representations of the colonised subject as scientific, objective knowledge (Ashcroft, Griffiths \& Tiffin, 2003, p. 85). It is not enough for the coloniser to control the present and the future of the colonised, claims Fanon (1971); it must also "rewrite their past by distorting, disfiguring and destroying it" (p. 210). To control a people's culture is to control their tools of selfdefinition in relation to others, therefore dominant cultures typically act in an ethnocentric way in defining their identity and identity of all 'others,' creating the "illusion of white superiority as an unquestionable factual reality" (Tinker, 1993, p. 118). What is more, Indigenous people have "internalised" the misconception of their inferiority just as deeply as whites have and thus participate in their own oppression (ibid.). By recalling the collective memories from the rich tribal past and emphasising the Indigenous peoples' resourcefulness and resilience, Leane's poetry intervenes in European discourses that have subverted traditional notions of culture and identity by imposing constructs incompatible with reality. As such, it prepares the grounds for the recovery and re-creation of Indigenous identity and culture.

The opening poem, "Camp," is also the celebration of Indigeneity and counters the ostensible invisibility of Indigenous people, their culture and history. As the title suggests, it is an idyllic description of harmonious tribal life, of times, when a child "learnt the country from her mother's hip," when "men, women and children [were] chortling" with glee at wonders of nature, when future was "bountiful" and "sleeping babies [were] dreaming peacefully" by the camp fire (Leane, 2010, p. 4). As an insight into the everyday dynamics of life that is in sharp contrast with the Indigenous experience grounded in suffering, deprivation and neglect laid 
bare later in the collection, the poem leaves the reader utterly unprepared for the appalling colonial reality addressed in all other poems.

Indeed, all subsequent poems are narrations about "centuries of White-mares" (Leane, 2010 , p. 5) and can be read as a list of wretched conditions that pertain to the Indigenous community's circumstances. Aroused by both her anger at those inflicting injustice on other people and her affection for those experiencing the inhumanity of racial subordination, Leane condemns the brutalising effects of the British invasion, which made "sovereign Aboriginal land terra nullius [nobody's land] and Aboriginal peoples vox nullius [people with no voice]" (Heiss \& Minter, 2008, p. 2). Focused on marginalised women's voices, Leane reflects on slavery, confiscation, incarceration, deaths in custody, child removal and other social wounds that do not match with a popular myth about Australia as a country of peace, opportunity and prosperity:

\author{
They raped my Mother country with their boats, \\ their diseases, their greed, their science and spilt \\ our blood to desecrate our land. \\ They raped my mother and enslaved her precious children \\ to turn our land into their paradise of \\ wool, wheat, workers, wealth and whiteness. (Leane, 2010, p. 11)
}

In compiling a catalogue of evidence to show and interrogate the patterns that established the whites as superior and non-whites as inferior, Leane constantly juxtaposes both cultures and philosophies, emphasizing the Indigenous peoples' spiritual and emotional depth, as well as their non-violent adaptability and resourcefulness. These qualities not only enabled them to survive in a hostile, morally decayed and emotionally sterile white environment, but also distinguish them from this environment. Clearly, Leane challenges both the whites' false, myth-laden perception of Indigenous people and the whites' images of themselves. For this reason, and following oral tradition, she piles on fact after fact about the moral vices or physical shortcomings of those who "left their mother country to conquer, rape, tame and subdue [hers]" (Leane, 2010, p. 9).

It is evident that Leane relies heavily on her Aboriginality for texture, diction and rhythm. Although she does not speak from her experience alone, her poems are deeply personal. A good example is the poem "Dark Secrets," which is both a powerful protest against the coloniser's practice of not only taking someone else's land by force but also imposing the system that enshrines the racialised hierarchies, and a heartbreaking intimate mourning for the times of harmonious and happy life of their ancestors. In describing Indigenous peoples' past and present traumatic conditions and mobilising various strategies of indictment and advocacy in the service of social justice agendas, Leane passionately engages non-Indigenous readers, evoking in them strong feelings of guilt, shame and remorse. "They keep us locked away like / dark secrets. / Never hearing our cries, / never seeing our misery, / never feeling our hunger" (2010, p. 14), says Leane, relentless in her criticism. Sharp, accusatory tone gives way to observations made in the manner of English mock-epic poetry: "They say God made all people / just not quite the same and / they are as close to angels as / we are to apes" (2010, p. 14). Final fusion of intimate narrative sentences with a set of rhetorical questions enforces a choric quality of the poem and turns it into a lamentation:

\footnotetext{
"Why did God make us dark secrets?"

My sister moans.

"Why didn't he keep us dark secrets?"

I ask.

We were happy undiscovered. (Leane, 2010, p. 14)
} 
Leane often experiments with various linguistic structures, particularly with rhetorical questions that are similarly underpinned with sardonic bitterness as those above. By employing this stylistic marker, the poet establishes an ambiguous conversational tone to hint at the passivity of white Australia, the attitude that Mills (2007) considers the whites' "cognitive handicap," when it comes to the recognition of racial discrimination and oppression (p. 15). In Leane's poetry, a textual illusion of a discourse is also established with other syntactic devices, such as a direct address to the reader or satirical antithesis. However, the aim behind these devices is always the same - to intervene in the ongoing disenfranchisement by white Australians and to oppose to the image of her people "manufacture[d] through literary phases in the consciousness of the coloniser" and ingrained within the oppressed themselves, as Leane writes in the above mentioned article (2010, p. 33). It can probably be argued that, exposing the Australian government's failure to effectively address the indicators of Indigenous peoples' disadvantage and pointing to the white Australians' position of privilege, the poem not only creates what Wendy Brady calls "a zone of discomfort around notions of what it means in contemporary Australia to be black" (Andrew, 1998, p. 15), but also enacts a strong political and social imperative.

Most of Leane's attention is paid to Indigenous women, to their strength and resilience even in times when they suffer the most severe oppression. Socially excluded, they find solace in their inner world, filled with warmth, tenderness and love, which is diametrically opposed to the shallow values of white women's world. They "protect their modesty beneath / layers of pale cloth, lace, hooks, buttons and laces," the so-called "marks of civilisation, success and gentility," Leane ironically observes in the poem "Handmaiden" (Leane, 2010, p. 22). The treatment of white women with irony and ridicule is particularly persistent in the poem "White Woman's Burden," in which the initial playful mockery at the expense of their rigid conventionality and emotional coldness turns into hyperbolically scornful tones: "If it weren't for us these good / women could be in their mother / country, calmed and soothed by / her soft, pastel beauty and kind, gentle skies" (2010, p. 18). Verbally inventive and sardonic, the final stanza closes with the lines: "We rob them of their beauty they say! / Their gentility and their sophisticated manners are / dying in our harsh land, under our hot sun with our heathen people" (2010, p. 18).

Leane's critical attitude towards governmental bodies and their failed prevention of ongoing creation of social structures that reinforce the white supremacy is particularly powerful when she writes about the atrocities performed in the name of "civilising the uncivilised." Her resentful voice, which gains poignancy by the ironic subtleties of her statements, culminates in the assertion:

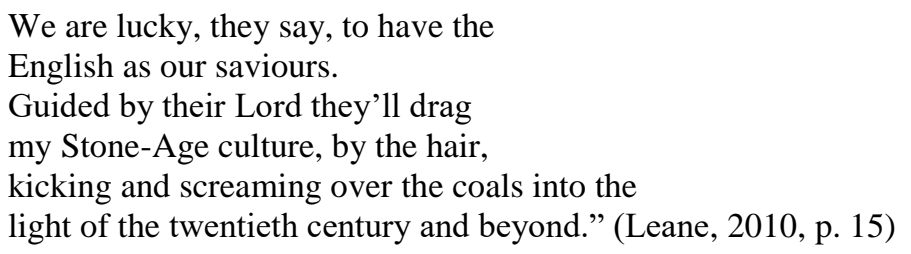

The poet's articulation of the tyranny of oppression and abuse, arrogance of power, and wilful destruction of people whose skin colour not only reasserts the root of the permanently imposed injustice but is also associated with death and distress, relies on repetitious formulas to indicate the perceived impossibility to escape such a predicament. In an accusatory and disconcertingly direct poem, "History: They Write Us Wrong," the political, economic and cultural disenfranchisement of Indigenous minority is addressed with particularly piercing criticism. Structured as a sustained argument and exposition and characterized by a style that denotes Leane's passionate interest in the issues, while remaining calm and subtly ironic, the 
poem condemns white Australian colonialist authority, established and preserved through the creation and repetition of discriminatory identities of those belonging to the communities of colour. It provides an extensive list of injustices of colonial discourse--"We talked our men strong, brave, noble [...]. / They write our men lazy, dirty, ignoble, thieves, slaves, drunks"and objects to the mainstream history, with its "distorted black images" and "lies [...] strewn and scattered across pristine pages for / future generations to read us by" (Leane, 2010, p. 13). In the last stanza, Leane observes: "Their pens brand us so deep it stands us to the bone," confirming the power of writing, that is, the importance of a text as a site of control and as a "highly effective instrumentality for the determination of the 'natives' under the sign of the Other" (Ashcroft, Griffiths \& Tiffin, 2003, p. 7). ${ }^{14}$

In several poems, Leane plays with the colours black and white to establish a contrasting picture of the lives of subjugated and subjugating people. The poem "From Black to White," for example, begins with a vivid presentation of once joyful and rewarding tribal life, when the "world was full of colour" (Leane, 2010, p. 12). The arrival of white aggressors overturns this deceptive appearance and the reader is taken into the haunted reality of the colonised nation:

\author{
White washed everywhere. \\ No more red, no more blue, no more yellow, green, \\ purple, orange or brown. \\ No more grey. \\ Only black and white now only white and black \\ only good and evil, free and captive, master and slave \\ rich and poor, better and worse, have and have-nots \\ propertied and dispossessed, us and them \\ Black and White \\ White and Black. (Leane, 2010, p. 12)
}

Proceeding in this fashion, the poem compiles a catalogue of evidence to expose and unsettle a black-white binarism in Australian society, a European discourse that proclaims and reinforces the persisting validity of colonialist authority: "White supremacy, black destruction / white nation / black burial ground / white power, black oppression / white life, black death" (Leane, 2010, p. 12). Creating a productive disordering of presupposed irrevocable binaries, the poem is a true postcolonial text, challenging - in Mignolo's words - the "authority and legitimacy of Euro-centred epistemology," that is, "assuming or explicitly declaring" the inferiority of all those positioned outside "European categories of proficiency and identity" (2005, p. 386).

The Assiniboine Sioux playwright William S. Robe has observed that, when people of color do the writing, it is always political because they empower themselves and take control of their past, present and future (Pulitano, 1998, p. 19). This is precisely what Leane's poetry does. With its "counter-discourse," as Tiffin (2003) calls a postcolonial subversion and dismantling of the dominant European discourses, it constitutes a radical reassessment of Australian social history and affirms the Indigenous Australians' authentic rather than an imposed cultural personality (p. 95). In this way, it prepares the grounds for the society that, in Bhabha's words, "entertains differences without an assumed or imposed hierarchy" (1994, p. 4). Given the present social and political situation in the world, characterised by a critical lack of productive cultural interaction, Leane's effort to question the foundations of white supremacy in Australia can be read from a much wider perspective. 


\section{CONCLUSION}

My aim in this article has been to investigate how Leane's poetry functions as a site of resistance against the racialised nature of social policy in Australia. It has shown that Leane's verse is impressive because of its collective good for the society, rather than because of its aesthetic purity. Documenting the violence of colonial imposition and scrutinising the means by which Europe imposed and maintained its dominant discourses, Leane creates a readership that is challenged to listen to her interrogative voice either through self-recognition or as a witness. Her poetry rhetorically indicts the "coloniality of knowledge and of being," as Mignolo (2005) refers to the state of being deprived of the "potential to know, to understand and to be" and through the critique contributes to the "undo[ing of] the racist structure of the colonial matrix of power" (p. 391). With its demand for "equal rights, opportunities and housing, better health, better education, everything equal" (Brewster, O'Neill, Van Den Berg, 2000, p. 189) - the major issues faced by Indigenous Australians today and common to many other minority groups that are placed in subaltern relations of power - Leane's poetry, just as Indigenous Australian literature in general, rapidly gains importance and expands its global readership.

\section{END NOTES}

\footnotetext{
${ }^{1}$ The Indigenous people of Australia are Aboriginal and Torres Strait Islander people.

${ }^{2}$ In 1788, when the British invaded the continent, Australia was not terra nullius (nobody's land) as claimed by the colonisers to justify the invasion. On the contrary, about 600,000-1,000,000 Indigenous Australians lived there. In less than 100 years, their number dramatically decreased to about 80,000.

${ }^{3}$ I briefly introduced Leane's poetry in my 2013 Delo article. https://www.delo.si/kultura/knjizevnilisti/sodobna-aboriginska-lirika.html
}

${ }^{4}$ As the Australian sociologist Ghassan Hage has observed, dignity and social hope, access to which seems to be exclusively a white entitlement, allows people to imagine a future for themselves, whereas the withholding of it from minority constituencies in effect denies them a participatory role in imagining the future of the nation (2003, p. 22).

${ }^{5}$ Leane has received several other awards, including the David Unaipon Award for her collection of stories Purple Threads (2011) and most recently the Oodgeroo Noonuccal Indigenous Poetry Prize.

David Unaipon published the collection of myths and legends, Native Legends (1929), which is considered the first literary work by an Australian Indigenous author. Oodgeroo (Kath Walker) was the first Indigenous Australian to publish a book of verse (We Are Going!, 1964) and an ardent political activist.

${ }^{6}$ The Symposium was organized to celebrate the fifth anniversary of the Australian literature supported project, recording information about, and research into, Aboriginal and Torres Strait Islander authors' work.

${ }^{7}$ In 1967, Australians voted in favour of changes to the Australian Constitution. The changes focused on two sections that discriminated against Indigenous peoples. The first section specified that federal laws did not apply to Indigenous population, which meant that they had different rights in different states and could not access federally funded services like social security and education. The second section prevented them from being included in the national census.

${ }^{8}$ In Australia's population of about 23 million, Indigenous Australians represent only about 2\% (470,000). The 1886 Half-Caste Act allowed authorities a forcible removal of children with more than 25 per cent Aboriginal blood from their parents and their assimilation in white families. This law was enforced until 1970 and in this time, more than 100,000 children, known as Stolen Generation, were forcibly separated from their families (Wheeler, 2013, p. xv).

${ }^{9}$ Indigenous Australians are mostly employed as unskilled workers.

10 Traditionally, Indigenous Australians did not know alcohol, so it is much more addictive to them than to white Australians (Wimmer, 2009, p. 115). Until 1967, selling alcohol to Indigenous population was banned. With the 1967 referendum, through which Black Australian communities became autonomous, the ban was repealed. According to Wimmer (2009), several politically correct advisors to the government did not consider alcohol as a problem, arguing that alcoholism was not any worse amongst Aborigines than amongst the whites. The ban was probably repealed because of "the colonialist discourse of alcoholism," as Eduardo Duran calls a historical awareness of the political causes of alcoholism, systematically utilised by the coloniser to disempower the colonised and reinforce its own power (Pearson, 2007, p. 122). 
${ }^{11}$ See my 2018 article The Aboriginal Intervention in Colonial Discourse: Challenging White Control of CrossRacial Intersubjectivity in GEMA Online ${ }^{\circledR}$ Journal of Language Studies.

12 I borrow the term from Ashcroft, Griffiths, and Tiffin's work The Empire Writes Back.

${ }^{13}$ I borrow the term from Tiffin (2003).

${ }_{14}$ According to Mignolo, in the modern/colonial world, race is »the key concept that enables and justifies oppression and exploitation (2005, p. 381).

\section{REFERENCES}

Andrew, B. (1998). Blak Babe(z)and Kweer Kat(z). Chippendale: Boomalli Aboriginal Artists Co-operative.

Amin, S. (2009). Evrocentrizem: Kritika Neke Ideologije. Ljubljana: Sophia.

Ashcroft, B., Griffiths G. \& Tiffin, H. (2003). Introduction. In B. Ashcroft, G. Griffiths \& H. Tiffin (Eds.). The Postcolonial Studies Reader (pp. 85-86). London, New York: Routledge.

Bhabha, H. (1997). The Other Question: The Stereotype and Colonial Discourse. In K. M. Newton (Ed.). Twentieth Century Literary Theory: A Reader (pp. 293-301). Palgrave, London: Macmillan Publishers Limited.

Bhabha, H. (1994). The Location of Culture. London, New York: Routledge.

Brewster, A. (2015). Giving This Country a Memory: Contemporary Aboriginal Voices of Australia. Amherst: Cambria Press.

Brewster, A. (2008). Engaging the Public Intimacy of Whiteness: The Indigenous Protest Poetry of Romaine Moreton. Journal of the Association for the Study of Australian Literature. Special Issue: The Colonial Present, 56-78.

Brewster, A, O'Neill, A. \& Van Den Berg, R. (2000). Those Who Remain Will Always Remember. An Anthology of Aboriginal Writing. Fremantle: Fremantle Arts Centre Press.

Brisbane, K. (Ed.). (1996) Australia Plays: New Australian Drama. London: Nick Hoen Books.

Crow, B., Banfield, C. (1996). An Introduction to Postcolonial Theatre. Cambridge: Cambridge University Press.

Čerče, D. (2013). Sodobna aboriginska lirika: Temne skrivnosti avstralske staroselske pesnice Jeanine Leanne. Književni listi - Delo (Ljubl.), 30 April, p. 14.

Čerče, D. (2017). Black Australia 'Writes Back' to the Literary Traditions of Empire. CLCWeb: Comparative Literature and Culture. Vol. 19(4). http://docs.lib.purdue.edu/cgi/viewcontent.cgi?article=3158\&context=clcweb

Čerče, D. (2018). The Aboriginal Intervention in Colonial Discourse: Challenging White Control of Cross-Racial Intersubjectivity. GEMA Online ${ }^{\circledR}$ Journal of Language Studies. Vol. 18(1). http://doi.org/10.17576/gema-2018-1801-03

Davis, J., Chesson, K. (1988). Jack Davis: A Life Story. Melbourne: Dent.

Fanon, F. (1971). The Wretched of the Earth. Harmondsworth: Penguin.

Gonzales, M., Agostini, R. (Eds.). (2015). Aesthetics and Ideology in Contemporary Literature and Drama. Newcastle upon Tyne: Cambridge Scholars Publishing.

Griffiths, M. R. (2013). Indigenous Life Writing: Rethinking Poetics and Practice. In B. Wheeler (Ed.). A Companion to Australian Aboriginal Literature (pp. 15-33). Rochester, New York: Camden House.

Guha, R. (1998). Dominance without Hegemony. History and Power in Colonial India. Cambridge: Cambridge University Press.

Harkin, N. (2014). The Poetics of (Re)Mapping Archives: Memory in the Blood. Journal of the Association for the study of Australian Literature. Vol 14(3). 
https://openjournals.library.sydney.edu.au/index.php/JASAL/article/view/9909/9798 Hage, G. (2003). Against Paranoid Nationalism: Searching for Hope in a Shrinking Society. Annandale: Pluto Press.

Heiss, A., Minter, P. (Eds.). (2008). Anthology of Australian Aboriginal Literature. Montreal: McGull-Queen's University Press.

Johnson, B. (1990). Writing. In. F. Lentricchia, \& T. Mc Laughlin (Eds.). Critical Items for Literary Study (pp. 39-49). Chicago: University of Chicago Press.

Johnston, T. (2008). Australia Says 'Sorry' to Aborigines for Mistreatment. The New York Times 13 Feb.

Juvan, M. (2006). Literarna veda v rekonstrukciji: Uvod v sodobni študij literature. Ljubljana: LUD Literatura.

Kilner, K. \& Minter, P. (2014). The Black Words Symposium: The Past, Present, and Future of Aboriginal and Torres Strait Islander Literature. Journal of the Association for the study of Australian Literature. Vol 14(3).

https://openjournals.library.sydney.edu.au/index.php/JASAL/article/viewFile/9905/97 $\underline{94}$

Leane, J. (2010). Dark Secrets: After Dreaming (AD) 1887-1961. Berry, NSW: Press Press.

Leane, J. (2010). Aboriginal Representation: Conflict or Dialogue in the Academy. The Australian Journal of Indigenous Education. Vol 39, pp. 32-39.

Leane, J. (2017). Gathering: The Politics of Memory and Contemporary Aboriginal Women's Writing. Antipodes. Vol. 31(2), pp. 242-461.

Lipsitz, G. (2006). The Possessive Investment in Whiteness. Philadelphia, PH: Temple University Press.

Mignolo, W. (2005). On Subalterns and Other Agencies. Postcolonial Studies. Vol. 8(4), pp. 381-407.

Mills, C. (2000). Race and the Social Contract Tradition. Social Identities. Vol 6(4), pp. 441462.

Mills, C. (2007). White Ignorance. In. S. Sullivan \& N. Tuana (Eds.). Race and Epistemologies of Ignorance (pp. 13-38). New York: State University of New York Press.

Mills, C. (2015). Breaking the Racial Contract. Dissent. Vol 62(4), pp. 43-45.

Moreton, R. (2004). Post Me to the Prime Minister. Alice Springs: Jukurrpa Books.

Moreton, R., Taylor, A. \& Smith, M. J. (2000). Rimfire: Poetry from Aboriginal Australia. Broome: Magabala Books.

Netzley, P. (1999). Social Protest Literature: An Enyclopedia of Works, Characters, Authors and Themes. Santa Barbara, CA: ABC-CLIO.

Nowra, L (2007). Bad Dreaming: Aboriginal Men's Violence Against Women and Children. North Melbourne: Pluto Press.

Pearson, J. (2007). Acts of Transfer: The 1975 and 1975 Productions of Raven and Body Indian. In. S. Magelssen \& A. Haugo (Eds.). Querying Difference in Theatre History (pp. 114125). Cambridge Scholars Publishing.

Pulitano, E. (1998). Telling Stories Through the Stage: A Conversation with William Yellow Robe. Studies in American Indian Literatures. Vol. 10(1), pp. 19-44.

Renes, M. (2016). Anne Brewster: Giving This Country a Memory: Contemporary Aboriginal Voices of Australia. The Journal of the European Association for Studies of Australia. Vol. 7(1), pp. 93-96.

Said, E. (1994). Culture and Imperialism. New York: Vintage.

Sartre, J. P. (1965). Anti-Semite and Jew. Trans. George J. Becker. New York: Shocken.

Slemon, S. (2003). Unsettling the Empire: Resistance Theory for the Second World. In B. Ashcroft, G. Griffiths \& H. Tiffin (Eds.). The Postcolonial Studies Reader (pp. 104110). London, New York: Routledge. 
Suleri, S. (2003). The Rhetoric of English India." In B. Ashcroft, G. Griffiths \& H. Tiffin (Eds.). The Postcolonial Studies Reader (pp. 111-113). London, New York: Routledge. Sutton, P. (2001). The Politics of Suffering: Indigenous Policy in Australia since the 1970s. Anthropological Forum. Vol 11, pp. 125-173.

Tiffin, H. (2003). Postcolonial Literatures and Counter-discourse. In B. Ashcroft, G. Griffiths \& H. Tiffin (Eds.). The Postcolonial Studies Reader (pp. 95-98). London, New York: Routledge.

Tinker, G. (1993). Missionary Conquest. Minneapolis: Fortress Press.

Weaver, J. (1997). That the People Might Live: Native American Literatures and Native American Community. New York: Oxford University Press.

Wimmer, A. (2009). Autonomous Aboriginal Communities in Australia. Acta Neophilologica. Vol. 42(1-2), 111-122.

Wheeler, B. (2013). Introduction: The Emerging Canon. In B. Wheeler (Ed.). A Companion to Australian Aboriginal Literature (pp. 1-13). Camden House.

\section{ABOUT THE AUTHOR}

Danica Čerče is a Full Professor of Literatures in English at the Faculty of Arts, University of Ljubljana. Her research interests include contemporary American and Australian literature and translation studies. Čerče is the author of three monograph publications, several book chapters in edited collections, and articles in academic journals. She serves on the editorial board of Coolabah, and Steinbeck Review and is a current President of International Society of Steinbeck Scholars. 